\title{
Disease Progress of Black Dot on Tomato Roots and Reduction in Incidence with Foliar Applied Fungicides
}

\author{
H. R. Dillard and A. C. Cobb, Cornell University, New York State Agricultural Experiment Station, Department of \\ Plant Pathology, Geneva 14456
}

\section{ABSTRACT}

Dillard, H. R., and Cobb, A. C. 1997. Disease progress of black dot on tomato roots and reduction in incidence with foliar applied fungicides. Plant Dis. 81:1439-1442.

Progression of black dot caused by Colletotrichum coccodes was determined at regular intervals on roots of processing tomatoes growing in a naturally infested field. In 1993 and 1994, C. coccodes was first isolated from tomato roots 30 and 37 days after transplanting, respectively, which corresponded to the opening of flowers in the first flower clusters. Black dot incidence increased rapidly from the time when large green fruit were present to production of mature red fruit. In both years, C. coccodes was isolated from the roots of $97 \%$ of the plants at the postharvest sampling date (162 days after transplanting). Areas under the incidence disease progress curves were not significantly different in the 2 years of study $(1993=83.5,1994=86.9)$. Root decay was severe at the postharvest sampling, and sclerotia of $C$. coccodes were abundant on the roots. C. coccodes was isolated from 38 and $44 \%$ of the root segments in 1993 and 1994 , respectively. Areas under the disease progress curves for infected root segments were not significantly different in the 2 years of study $(1993=25.8,1994=33.9)$. In a separate study, chlorothalonil $(2.5 \mathrm{~kg} / \mathrm{ha})$ or mancozeb $(1.68 \mathrm{~kg} / \mathrm{ha})$ was applied at 7-, 10-, or 14-day intervals to tomato plants. Recovery of $C$. coccodes from root segments at harvest (113 to 118 days after transplanting) was significantly reduced in the chlorothalonil 7- or 10-day and mancozeb 10-day interval treatments in both years. However, the percentage of plants with black dot was not consistently reduced by fungicide applications.

Colletotrichum coccodes (Wallr.) S.J. Hughes is a cosmopolitan pathogen primarily found on vegetables in the Solanaceae $(3,10)$ and is recognized as the cause of anthracnose on fruit and black dot on roots of tomato (Lycopersicon esculentum Mill.). Although immature fruit may be infected, symptoms do not develop until the fruit ripen $(8,10,17,20)$. Initial symptoms appear on fruit as light brown flecks. As the disease progresses, the lesions enlarge, and become circular and sunken. Masses of salmon-colored spores are produced in the lesions in moist weather, and small black sclerotia form in mature lesions. The fungus survives in soil for several years as sclerotia associated with infested debris, or free in the soil $(1,11,15)$. Myceliogenic and sporogenic germination can occur $(24,28)$.

C. coccodes also may infect leaves and roots of tomato $(3,4,10,14,15,22,25)$ and potato plants $(5,19,27,29,30)$. Symptoms on the foliage are not prevalent in New

Corresponding author: H. R. Dillard

E-mail: HRD1@ cornell.edu

This research was supported in part by the North East Pesticide Impact Assessment Program, the New York State Tomato Research Association, and Furman Foods Inc.

Accepted for publication 24 August 1997.

Publication no. D-1997-0930-03R

(C) 1997 The American Phytopathological Society
York, but root infections are widespread on tomato and potato $(11,30)$. Initial symptoms of tomato root infections caused by C. coccodes are tan to brown discoloration of fine roots, progressing to extensive areas of cortical rot $(4,12,21)$. As the lesions mature, the fungus produces sclerotia in the colonized areas, hence the name "black dot disease" $(4,30)$. The cortical tissue containing the sclerotia may slough off of severely infected roots. In hydroponic systems, $C$. coccodes may cause a root rot and wilt of tomatoes (25).

In New York, anthracnose is the most consistent yield-limiting disease on processing tomatoes. It is particularly troublesome because regular rainfall, warm temperatures, and high humidity during the growing season are conducive for anthracnose development $(8,9,10)$. Incidence and severity of black dot on tomato roots in New York are variable (11). Previous research has shown that root colonization increases as plant age increases $(6,21)$, but the consensus in the literature is that black dot has little effect on plant growth $(3,18,20,21)$ and no effect on yield (21). Control of anthracnose is achieved by using multiple protectant fungicide applications $(10,13,23)$, but the effect of these fungicide applications on black dot development is not known. The objectives of this study were to determine the time and growth stage of tomato plants when black dot is observed in the field, to construct disease progress curves for black dot, and to determine the effect of foliar fungicide applications on incidence of black dot caused by $C$. coccodes.

\section{MATERIALS AND METHODS}

Experimental site. All trials were conducted in Field \#21 at the Vegetable Research Farm in Geneva, New York. The field is naturally infested with $C$. coccodes, Alternaria solani Sorauer, and Septoria lycopersici Speg., and is regularly planted with tomatoes to maintain high populations of these pathogens. The soil type is Honeoye fine sandy loam, $\mathrm{pH} 6.5$ to $7.2,2.1 \%$ organic matter, and is described as a deep, welldrained soil formed in high lime glacial till. Rainfall and irrigation by month totaled 7.0 $\mathrm{cm}$ in May, $6.9 \mathrm{~cm}$ in June, $11.4 \mathrm{~cm}$ in July, $4.5 \mathrm{~cm}$ in August, and $3.6 \mathrm{~cm}$ to 9 September 1993; $6.0 \mathrm{~cm}$ in May, $10.7 \mathrm{~cm}$ in June, $3.5 \mathrm{~cm}$ in July, $16.4 \mathrm{~cm}$ in August, and $0.5 \mathrm{~cm}$ to 7 September 1994.

Black dot disease progress. Tomatoes (cv. Early Pear) were seeded in the greenhouse on 15 and 16 April 1993, and on 14 and 15 April 1994. Thirty plants were obtained immediately prior to transplanting and assayed for root colonization to determine if root infections had occurred in the greenhouse. Tomatoes were transplanted on 18 May 1993 and 23 May 1994 in an area partitioned into six blocks containing six rows (9 m long on $1.5-\mathrm{m}$ centers) of tomatoes. Plants within the row were spaced approximately 23 to $28 \mathrm{~cm}$ apart. No fungicides were applied to these tomato plants during the growing season. At 3- to 4 -week intervals, 5 plants from each block were unearthed to determine incidence of black dot caused by $C$. coccodes.

Unearthed tomato root systems were gently shaken to remove large soil aggregates. The plant tops were discarded, and the main stems containing the root systems were brought to the laboratory where the roots were gently washed in tap water over a wire mesh screen (No. 10, 9 mesh, 2 $\mathrm{mm})$ to remove the remaining soil. The roots were examined for the presence of lesions, and 30 root segments, 1 to $1.5 \mathrm{~cm}$ in length, were cut from each plant. Root segments were selected from brown and necrotic areas on roots, corky roots, and lesions with sclerotia of $C$. coccodes. When symptoms were absent, segments were selected from root tips, stunted rootlets, and areas on the main root. The root segments were surface disinfested in $0.5 \%$ $\mathrm{NaOCl}$ for 4 min. Six root segments were placed on each of five 9-cm petri dishes containing V8 juice agar $(700 \mathrm{ml}$ of 
distilled water, $300 \mathrm{ml}$ Campbell V8 juice, 30 g Difco Bacto agar, 0.1 g chloramphenicol, $0.1 \mathrm{~g}$ streptomycin sulfate). The segments were incubated for 3 to 4 weeks at room temperature $\left(21\right.$ to $\left.24^{\circ} \mathrm{C}\right)$, and the number of colonies of $C$. coccodes were recorded.

Effects of foliar fungicide applications. In 1993, tomatoes (cv. Early Pear) were seeded in a soilless potting mix in the greenhouse on 15 and 16 April, and transplanted on 18 May. Seven treatments were arranged in a randomized complete block design with 6 replications per treatment. Each replicate plot was $9 \mathrm{~m}$ long on $1.5-\mathrm{m}$ centers. Plants within the row were spaced approximately 23 to $28 \mathrm{~cm}$ apart. Chlorothalonil (Bravo 720) treatments were applied at the rate of $2.5 \mathrm{~kg} / \mathrm{ha}$ and mancozeb (Penncozeb DF) treatments were applied at the rate of $1.68 \mathrm{~kg} / \mathrm{ha}$. All fungicide rates are given as the amount of active ingredient per hectare. Treatments were applied with a $\mathrm{CO}_{2}$-pressurized backpack sprayer delivering 468 liters/ha at 345 $\mathrm{kPa}$. Three flat fan nozzles (Spraying Systems 8003) were configured on the boom with 1 positioned over the top of the row and 1 nozzle positioned on each side of the row on $22.5-\mathrm{cm}$ drop pipes. Fungicide applications were initiated when the crown fruit were one-third of estimated full size.

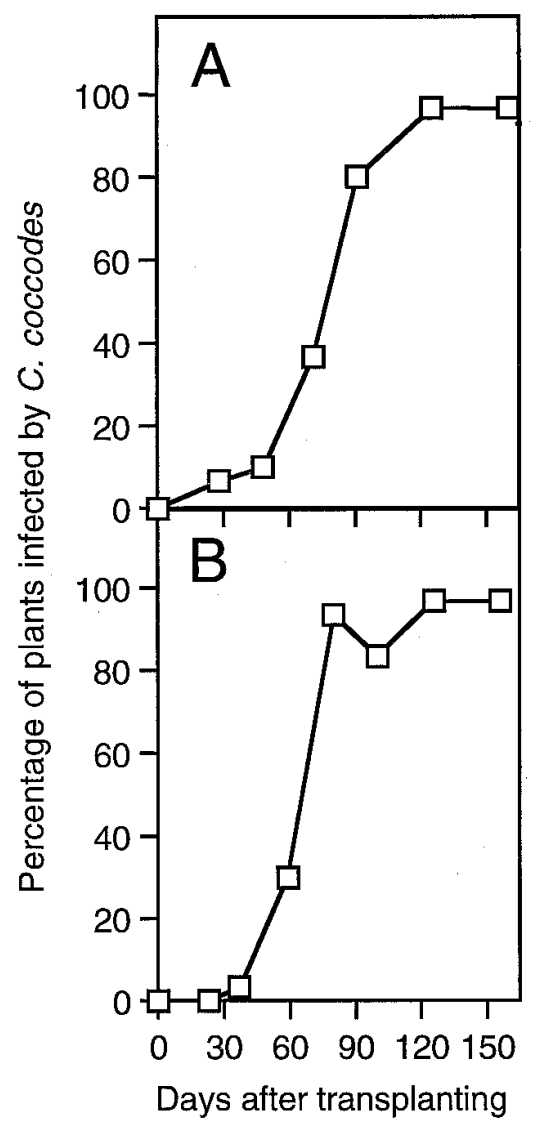

Fig. 1. Disease progress curves for black dot on tomato, caused by Colletotrichum coccodes: incidence on whole plants (A) in 1993 and (B) in 1994.
Three application schedules were used: 8 applications at 7-day intervals, 6 applications at 10-day intervals, and 4 applications at 14-day intervals.

The experiment was repeated in 1994 using the same tomato cultivar seeded in the greenhouse on 14 and 15 April, and transplanted 23 May. Tomato roots were harvested 12 September 1993 and 1994, by removing root systems from 5 plants in each replicate plot. Incidence of root colonization by $C$. coccodes was determined using the root assay previously described.

Statistical analysis. Root disease progress curves were constructed and the areas under the disease progress curves (AUDPC) were calculated using the trapezoid rule, where the area was approximated by joining the points at the observed times by line segments and calculating the area of the resultant trapezoids (2). Analysis of variance was performed on incidence and AUDPCs, and Fisher's protected least significant difference was used to separate means $(P=0.05)$.

\section{RESULTS}

Black dot disease progress. $C$. coccodes was not isolated from root samples obtained immediately prior to transplanting. In 1993, the fungus was isolated 30 days after transplanting, which corre-

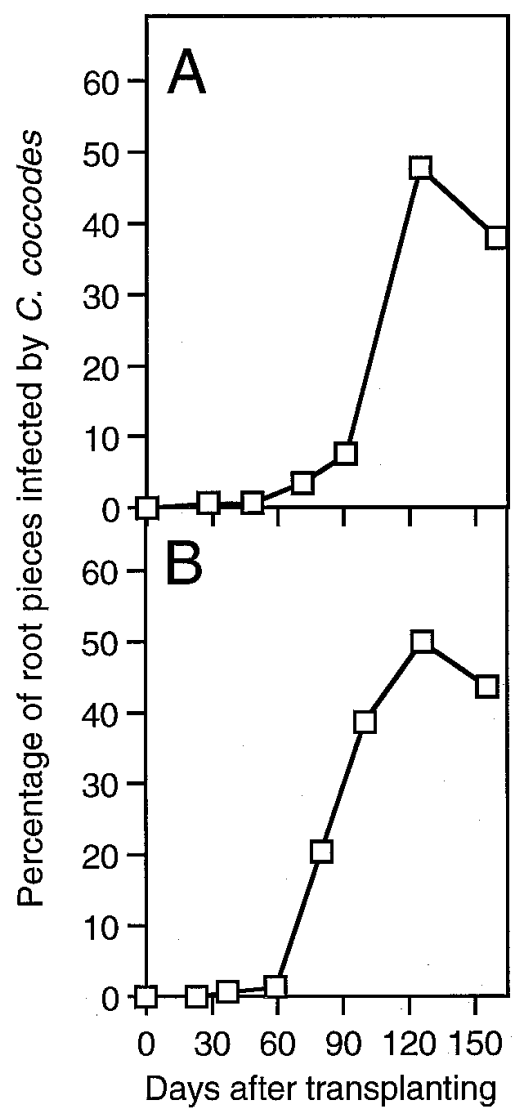

Fig. 2. Disease progress curves for black dot on tomato, caused by Colletotrichum coccodes: incidence on root segments (A) in 1993 and (B) in 1994. sponded to when the first flower buds were forming (Fig. 1A). Only 2 plants were infected, and the fungus was isolated from 1 root segment on each plant (Fig. 2A). Symptoms consisted of tan lesions, 1 to 3 $\mathrm{mm}$ in length. Small green fruit were present on the plants 48 days after transplanting, and $C$. coccodes was isolated from the roots of 3 plants. A major increase in isolation frequency occurred at 73 days after transplanting, when $C$. coccodes was detected from $37 \%$ of the plants and $3 \%$ of the root segments. Disease incidence increased rapidly between 73 and 127 days after transplanting (Fig. 1A, 2A). This period of time corresponded to the production of large green fruit (73 days) and mature red fruit ready for harvest (127 days). Root decay was severe in the postharvest sampling (162 days after transplanting), and sclerotia of $C$. coccodes were abundant on the roots (resulting in black dot). Heavily infected roots readily detached from the main stem at harvest, resulting in fewer infected roots to select from in the root assay procedure. At the postharvest sampling, C. coccodes was isolated from the roots of $97 \%$ of the plants and $38 \%$ of the root segments (Fig. 1A, 2A).

Results were similar in 1994. C. coccodes was first isolated 37 days after transplanting, which corresponded to bloom in the first flower cluster (Fig. 1B). Isolation frequency increased at 59 days after transplanting, when the fungus was detected in 9 plants. Disease increased rapidly between 59 and 126 days after transplanting (Fig. 1B, 2B), which corresponded to the production of green fruit (59 days) and harvest (126 days). At the postharvest sampling, $C$. coccodes was isolated from the roots of $97 \%$ of the plants and $44 \%$ of the root segments (Fig. 1B, 2B).

The AUDPC for whole plants were not significantly different in the 2 years of study $(1993=83.5,1994=86.9, P=$ 0.422). Similarly, AUDPC for infected root segments were not statistically different in the 2 years of study $(1993=25.8,1994=$ 33.9, $P=0.249$ ).

Effects of foliar fungicide applications. Foliar fungicides did not consistently reduce the percentage of plants with black dot root rot at the final sampling date (Table 1). However, recovery of $C$. coccodes from root segments at harvest (118 and 113 days after transplanting in 1993 and 1994, respectively) was significantly reduced by applications of chlorothalonil at 7- or 10-day intervals and mancozeb at 10-day intervals in both years. Mancozeb applied at 7-day intervals and chlorothalonil applications at 14day intervals also significantly reduced the mean number of infected root segments in 1993 and 1994, respectively.

\section{DISCUSSION}

C. coccodes is an important pathogen causing anthracnose on tomato fruit $(8,9,10)$ 
and black dot on potato roots, tubers, and stems $(29,30)$ in New York. Although $C$. coccodes is readily isolated from tomato roots, black dot research has been preempted by research on control of the highly visible and yield-limiting disease, anthracnose. In this study, initial black dot infections were detected at flowering, and disease incidence and severity increased with the production and maturation of the tomato fruit. These data are consistent with those of Hornby (15), who observed that the rate at which $C$. coccodes colonized roots was initially slow but increased with the onset of flowering; and with those of Last and Ebben (21), who observed a rapid increase in black dot symptoms on tomato roots towards the end of the season. At the post-harvest sampling date in our study, root decay was severe and most of the roots were dark brown and covered with small black sclerotia of $C$. coccodes. Complete samples of severely infected root systems were impossible to obtain because the infected roots readily detached from the main stem at harvest, and were left in the field or had sloughed off prior to our sampling. As severely infected roots were washed in the assay procedure, portions of the cortical tissue were observed sloughing off. Attempts were made to capture the tissue on screens, but some tissue was lost. In both years of study, loss of the colonized cortical tissue resulted in a noticeable decline at the postharvest sampling date on the disease progress curves for infected root segments (Fig. 2A, 2B).

Foliar fungicides applied in this study did not consistently reduce the percentage of plants with black dot. However, fungicides applied at 7- or 10-day intervals significantly reduced the mean number of infected root segments. The mechanism for reduction in black dot is uncertain. One possibility is that the foliar applied fungicides are washed from the leaves and fruit onto the roots. However, widespread redistribution in soil of foliar applied fungicides is not common. Chlorothalonil has high binding and low mobility in silty loam and silty clay loam soils (26). Although mancozeb is unlikely to infiltrate groundwater, ETU, a metabolite of mancozeb, has the potential to leach through the soil (26).
Neither compound is registered for control of root diseases. A second possibility is that conidia are washed from infected fruit onto the roots, and therefore controlling anthracnose on the fruit reduces the inoculum available for the roots. However, in our disease progress study, root infections were first detected at flowering and continued to increase prior to lesion development on the fruit. Huisman (16) proposed that as roots grow and explore more soil with time, they come in contact with increasing numbers of propagules, and the resulting root disease progress curves parallel root growth curves. The black dot progress curves constructed in this study resemble the typical sigmoid curve of root growth (16). A third possibility is that the foliar fungicides reduced the foliar-disease stress on the tomato plants and allowed natural defense mechanisms to protect the roots from colonization by $C$. coccodes. In our study, the tomato foliage in the unsprayed plots was heavily infected with $A$. solani and S. lycopersici. Both pathogens initiate disease on the older leaves, and disease severity increases as the plants mature and are stressed by fruit production. Fungicide applications reduced incidence and severity of both of these diseases. Stress has been identified as a contributing factor in the development of black dot on potato $(7,27)$ and tomato $(6,21)$, and removing fruit from plants as soon as they develop suppresses development of black dot on tomato (6).

Control strategies for $C$. coccodes on tomato fruit rely heavily on the use of multiple foliar fungicide applications $(10,13,23)$. In contrast to potatoes $(27,29,30)$, control recommendations for tomatoes have not included specific strategies for black dot because the disease has little effect on plant growth $(3,18,20,21)$. However, black dot should not be completely ignored in tomato disease management strategies because tomato roots infected with $C$. coccodes produce large numbers of sclerotia with long term survival ability (11). Over time, infected roots could significantly increase the inoculum density of $C$. coccodes in field soils (1) and result in increased anthracnose incidence and severity.
ACKNOWLEDGMENTS

The authors gratefully acknowledge assistance and advice from W. Garman and N. Ntahimpera, and the summer assistance of D. Brink, K. Jensen, D. Cobb, J. Ingram, and K. McCormick.

\section{LITERATURE CITED}

1. Barkdoll, A. W., and Davis, J. R. 1992. Distribution of Colletotrichum coccodes in Idaho and variation in pathogenicity on potato. Plant Dis. 76:131-135.

2. Campbell, C. L., and Madden, L. V. 1990. Introduction to Plant Disease Epidemiology. John Wiley \& Sons, New York.

3. Chesters, C. G. C., and Hornby, D. 1965. Studies on Colletotrichum coccodes II. Alternative host tests and tomato fruit inoculations using a typical tomato root isolate. Trans. Br. Mycol. Soc. 48:583-594.

4. Colquhoun, T. T. 1941. Black dot root rot of tomatoes. J. Agric. South Aust. 44:572-575.

5. Dashwood, E. P., Fox, R. A., and Perry, D. A 1992. Effect of inoculum source on root and tuber infection by potato blemish disease fungi. Plant Pathol. 41:215-223.

6. Davet, P. 1972. Research on Colletotrichum coccodes (Wallr.) Hughes. IV. Development of the fungus on tomato in relation to plant and root age. Phytopathol. Mediterr. 11:103108.

7. Dickson, B. T. 1926. The "black dot" disease of potato. Phytopathology 16:23-40.

8. Dillard, H. R. 1987. Tomato anthracnose. Page 735.70 in: Vegetable Crops Fact Sheet. Cornell Cooperative Extension.

9. Dillard, H. R. 1989. Effect of temperature, wetness duration, and inoculum density on infection and lesion development of Colletotrichum coccodes on tomato fruit. Phytopathology 79:1063-1066.

10. Dillard, H. R. 1992. Colletotrichum coccodes: The pathogen and its hosts. Pages 225-236 in: Colletotrichum: Biology, Pathology and Control. J. A. Bailey and M. J. Jeger, eds. CAB International, Wallingford, UK.

11. Dillard, H. R., and Cobb, A. C. 1993. Persistence of Colletotrichum coccodes on tomato roots and in soil. Phytopathology 83:1345.

12. Dunn, E., and Roy, A. K. 1970. Infection of tomato seedlings by Colletotrichum coccodes (Wallr) Hughes. Plant Pathol. 19:196-197.

13. Fulling, B. A., Tigchelaar, E. C., and Latin, R. 1995. Integration of host resistance and weather-based fungicide scheduling for control of anthracnose of tomato fruit. Plant Dis. 79:228-233.

14. Hausbeck, M. K., and Linderman, S. D. 1992. Influence of dew period and temperature on infection of tomato foliage by Colletotrichum coccodes. Phytopathology 82:1091.

15. Hornby, D. 1968. Studies on Colletotrichum coccodes III. Some properties of the fungus in soil and in tomato roots. Trans. Br. Mycol. Soc. 51:541-553.

Table 1. Effect of fungicide applications on infection of tomato roots by Colletotrichum coccodes

\begin{tabular}{|c|c|c|c|c|c|}
\hline \multirow[b]{2}{*}{ Treatment $^{b}$} & \multirow[b]{2}{*}{ Application interval } & \multicolumn{2}{|c|}{ Plants with infected roots $(\%)^{a}$} & \multicolumn{2}{|c|}{ Mean no. infected root segments } \\
\hline & & 1993 & 1994 & 1993 & 1994 \\
\hline Nontreated & & 97 & 100 & 9.5 & 16.1 \\
\hline Chlorothalonil & 8 sprays, 7-day & 90 & 93 & 6.2 & 9.1 \\
\hline Chlorothalonil & 6 sprays, 10 -day & 93 & 80 & 5.1 & 5.7 \\
\hline Chlorothalonil & 4 sprays, 14 -day & 97 & 93 & 7.4 & 10.8 \\
\hline Mancozeb & 8 sprays, 7 -day & 90 & 90 & 6.8 & 14.8 \\
\hline Mancozeb & 6 sprays, 10 -day & 80 & 100 & 4.9 & 12.2 \\
\hline Mancozeb & 4 sprays, 14 -day & 93 & 100 & 8.4 & 18.0 \\
\hline $\operatorname{LSD}^{c}(P=0.05)$ & & 14 & 11 & 2.5 & 3.2 \\
\hline
\end{tabular}

a Plants with infected roots at harvest, 12 September 1993 and 1994.

${ }^{\mathrm{b}}$ Chlorothalonil applied as Bravo 720, $2.5 \mathrm{~kg} / \mathrm{ha}$ active ingredient. Mancozeb applied as Penncozeb DF, $1.68 \mathrm{~kg} / \mathrm{ha}$ active ingredient.

${ }^{\mathrm{c}}$ Least significant difference. 
16. Huisman, O. C. 1982. Interrelations of root growth dynamics to epidemiology of root-invading fungi. Annu. Rev. Phytopathol. 20:303-327.

17. Illman, W. I., Ludwig, R. A., and Farmer, J. 1959. Anthracnose of canning tomatoes in Ontario. Can. J. Bot. 37:1237-1246.

18. Jakubczyk, H. 1962. The investigation on the parasitism of Colletotrichum atramentarium on tomato plants. II. The investigation on the pathogenicity of $C$. atramentarium in the infection experiments on tomato plants. Acta Agrobot. 12:231-259.

19. Johnson, D. A. 1994. Effect of foliar infection caused by Colletotrichum coccodes on yield of Russet Burbank potato. Plant Dis. 78:10751078.

20. Kendrick, J. B., and Walker, J. C. 1948. Anthracnose of tomato. Phytopathology 38:247-260.
21. Last, F. T., and Ebben, M. H. 1966. The epidemiology of tomato brown root rot. Ann. Appl. Biol. 57:95-112.

22. Pantidou, M. E., and Schroeder, W. T. 1955. Foliage as a source of secondary inoculum for tomato anthracnose. Phytopathology 45:338345.

23. Precheur, R. J., Bennett, M. A., Riedel, R. M., and Dudash, P. J. 1990. Effect of tomato variety on efficacy of chemical control of anthracnose, 1988. Biol. Cult. Tests Control Plant Dis. 5:35.

24. Sanogo, S., and Pennypacker, S. P. 1997 Factors affecting sporogenic and myceliogenic germination of sclerotia of Colleto trichum coccodes. Plant Dis. 81:333-336.

25. Schneider, R. W., Grogan, R. G., and Kimble, K. A. 1978. Colletotrichum root rot of greenhouse tomatoes in California. Plant Dis. Rep.
62:969-971.

26. Seyler, L. A., Allan, J. W., Rutz, D. A., and Kamrin, M. A. 1994. EXTOXNET: Extension Toxicology Network Pesticide Information Notebook. Cornell Univ., Ithaca, NY.

27. Stevenson, W. R., Green, R. J., and Bergeson,

G. B. 1976. Occurrence and control of potato black dot root rot in Indiana. Plant Dis. Rep. 60:248-251.

28. Tu, J. C. 1980. The ontogeny of the sclerotia of Colletotrichum coccodes. Can. J. Bot. 58:631-636.

29. Uribe, E., and Loria, R. 1994. Response of Colletotrichum coccodes to fungicides in $\mathrm{vi}$ tro. Am. Potato J. 71:455-465.

30. Zitter, T. A., Hsu, L., and Halseth, D. E. 1989 Black dot disease of potato. Page 725.70 in: Vegetable Crops Fact Sheet. Cornell Cooperative Extension. 